\title{
ISHLAH DALAM TAKHARUJ MENURUT HANAFIYAH VERSUS ISHLAH DALAM KOMPILASI HUKUM ISLAM (Analisis Kebijakan Hukum)
}

\author{
Elfia \\ Fakultas Syari'ah UIN Imam Bonjol Padang \\ J1. Prof. Mahmud Yunus Lubuh Lintah Padang \\ e-mail: elfiauinib@gmail.com
}

\begin{abstract}
This study aims at analyzing the two forms of legal policy in the division of inheritance by using the principle of ishlah. The takharuj practices that develops in the Hanafi school allows the giving of inheritance rights to the heirs before the property is distributed (before the heirs dies) in the presence of the willingness of the other heirs. The term Ishlah is understood by giving rewards in exchange for the part of the resigned heirs. The principle of ishlah which permits the distribution of inheritance under the agreement of the heirs is also regulated in the Compilation of Islamic Law Article 183. But in that article, the existence of ishlah can be done after the heirs died (after the division of inheritance). This research is a library research by using normative law approach and analyzing the data by content analysis. As the findings from this study, there are several weak points in the completion of the takharuj so that clerics outside Hanafiyah school did not practice it. These weak points potentially violate the qath'i propositions and general principles in muamalah maaliyah. The peace (ishlab) in the Compilation of Islamic Law is easier to follow and does not violate the qath'i proofs in the Qur'an and Hadith.
\end{abstract}

Kata kunci: ishlah, takharuj, kebijakan hukum

\section{PENDAHULUAN}

$F_{\text {erumusan fikih mawaris penuh }}$ ketika adanya benturan hukum dengan hukum untuk mengakomodir rasa keadilan masyarakat. Kebijakan hukum yang dibuat oleh sahabat dalam masalah kewarisan, dapat dilihat dari beberapa bentuk penyelesaian kewarisan seperti dalam masalah 'aul dan radd.

Aul dan radd merupakan dua masalah yang muncul dalam penyelesaian kewarisan, ketika harta warisan yang ada tidak mencukupi untuk dibagikan sesuai dengan furudh masing-masing ahli waris dan ketika harta warisan berlebih setelah ahli waris menerima hak sesuai dengan furudh masing-masing. Penyelesaian secara 'aul dan radd merupakan sebuah kebijakan hukum yang didasarkan kepada keadilan untuk semua ahli waris, karena jika dalam pembagian tetap mengacu kepada pelaksanaan hukum menurut adanya akan menemui kesulitan. Kesulitan tersebut dapat disebabkan karena harta warisan yang ada tidak mencukupi untuk memenuhi hak masingmasing ahli waris atau bisa juga harta warisan melebihi dari furudh yang ada.

Dalam keadaan seperti ini diperlukan sebuah kebijakan yang dapat 
diterima oleh semua pihak tanpa melanggar aturan hukum yang mesti dijalankan. Demikian juga halnya dalam masalah gharawain atau umariyah, akdariyah dan al kharqa merupakan masalah dalam kewarisan yang pernah diputuskan oleh Umar dan diterima oleh mayoritas sahabat yang kemudian diikuti oleh jumhur ulama. Kebijakan hukum yang dibuat oleh Umar bin al-Khaththab juga menjadi sebuah solusi yang agaknya dapat mengatasi dua hal tersebut.

Kebijakan hukum seperti beberapa contoh di atas bukan saja berlaku dan pernah dilakukan oleh sahabat seperti Umar bin al-Khaththab dan sahabat lainnya. Namun dalam beberapa putusan yang dikeluarkan oleh Mahkamah Agung, ternyata kebijakan hukum juga telah banyak menjadi solusi dalam penyelesaian kasus yang diajukan ke Mahkamah Agung. Umpamanya Putusan MA No.368 K/AG/1995 dan No. 16 K/AG/2010, Mahkamah Agung memberikan hak kepada ahli waris yang bebeda agama. Menurut ketentuan hukum, beda agama menjadi penghalang seseorang menerima hak waris. Namun dalam keputusan Mahkamah Agung, ahli waris yang terhalang mendapatkan warisan karena berbeda agama dengan pewaris, diselesaikan dengan kebijakan hukum. Kebijakan itu ditempuh dengan cara memberikan hak dalam bentuk wasiat wajibah.

Selain beberapa bentuk kebijakan hukum yang dilakukan dalam pembagian warisan, dalam mazhab Hanafiyah juga berkembang bentuk kebijakan hukum lain yang diistilahkan dengan takharuj. Jika dilihat konsep takharuj yang dikemukakan oleh ulama mazhab Hanafi, secara zahir terlihat takharuj merupakan tindakan tidak senang dengan hukum Allah SWT sehingga dilakukan upaya untuk mengoreksi hukum Allah SWT tersebut, sekalipun secara kenyataan bukan demikian adanya. Kerelaan para pihak diperlukan dan menentukan dalam kebijakan secara takharuj. Seandainya kerelaan dari para pihak tidak ada, maka penyelesaian hukum akan kembali sesuai dengan ketentuan hukum Allah.

Dilihat dari prakteknya, takharuj pada dasarnya merupakan jual beli warisan yang dilakukan antara seorang ahli waris dengan ahli waris lain, bisa juga jual beli yang dilakukan beberapa orang terhadap harta warisan, sementara pewaris yang memiliki harta belum meninggal. Dalam kaitannya dengan permasalahan takharuj ini asas ijbari mempunyai kedudukan yang sentral dalam timbulnya perbedaan ulama tentang kedudukan hukumnya (Syarifuddin, 2004: 3). Pemahaman terhadap asas ijbari inilah yang membuat terjadinya perbedaan pendapat terhadap hukum takharuj dalam pembagian harta warisan. Kalangan yang memahami ijbari dengan pengertian memaksa dalam hal bagian yang diterima ahli waris yang akan menerima dan cara pembagian harta tersebut memandang takahruj menyimpang dari prinsip-prinsip kewarisan Islam. Sementara yang lain memandang bahwa ijbari yang dimaksud bukanlah hal itu, melainkan dalam hal jumlah bagian dan kriteria ahli waris saja sehingga mengenai pembagiannya dapat diserahkan kepada ahli waris.

Prinsip ishlah yang membolehkan adanya pembagian warisan berdasarkan kesepakatan ahli waris ini, juga diatur dalam Kompilasi Hukum Islam Pasal 183. Dalam pasal tersebut dinyatakan bahwa 
"para ahli waris dapat bersepakat melakukan perdamaian dalam pembagian harta warisan, setelah masing-masing menyadari bagiannya". Pasal ini mengisyaratkan adanya kebijakan hukum dengan cara ishlah dalam pembagian warisan, dengan ketentuan ahli waris telah mengetahui bagian masing-masing terlebih dahulu. Berdasarkan pasal 183 Kompilasi Hukum Islam di atas, KHI juga menawarkan kebijakan hukum dalam bentuk ishlah, namun dalam teksnya menunjukkan bahwa ishlah itu dilakukan setelah pewaris meninggal.

Berdasarkan uraian di atas, kajian ini penting untuk diangkat sebagai sebuah penelitian karena bertujuan untuk mencari dari dua kebijakan hukum yang dilakukan dalam penyelesaian kewarisan itu, mana yang paling baik untuk diterapkan dan paling sedikit benturannya dengan dalil-dalil yang ada. Oleh karena itulah diperlukan penelitian terhadap kebijakan hukum dalam takharuj dan Pasal 183 Kompilasi Hukum Islam. Pentingnya penelitian ini untuk melihat titik-titik temu dan titik lemah takharuj. Di samping itu juga melihat konsep ishlah yang ditawarkan KHI yang tidak tampak adanya perbenturan dengan dalil yang ada dengan rumusan masalah kebijakan hukum mana yang lebih tepat dari dua kebijakan itu untuk diterapkan dalam kewarisan Islam di Indonesia?

Dalam upaya memperoleh data dan rumusan yang jelas dalam menjawab semua permasalahan dalam penelitian ini, maka digunakan penelitian kepustakaan (library research). Pendekatan yang digunakan dalam penelitian ini adalah pendekatan hukum normatif dengan metode content analisis. Jenis data yang digunakan dalam penelitian ini adalah data sekunder. Data sekunder terdiri dari bahan hukum primer, bahan hukum sekunder dan tertier.

Sejauh ini penelitian yang membahas tentang hukum kewarisan Islam sudah dilakukan oleh peneliti-peneliti lain, namun objek penelitian yang telah ada bukan mengenai objek yang penulis teliti, di antaranya:

Pertama, Amir Syarifuddin, Pelaksanaan Hukum Kewarisan Islam dalam Lingkungan Adat Minangkabau, penulisan disertasi pada Program Pascasarjana IAIN Syarif Hidayatullah Jakarta, 1982. Penelitian ini menyimpulkan bahwa pelaksanaan hukum waris Islam dalam masyarakat Minangkabau sangat kental dengan nuansa kekeluargaan dan kekerabatan. Namun kekhususannya terletak pada corak garis keturuanan ibu (matrilineal) dalam praktek pembagian harta warisan.

Kedua, Ali Yasa Abu Bakar, Ahli Waris Sepertalian Darah: Kajian Perbandingan Terhadap penalaran Hazairin dan Penalaran Fikih Mazhab, Disertasi pada Program Pascarajana IAIN Sunan Kalijaga Yogyakarta, 1996. Penulisan ini berkesimpulan bahwa ijtihad Hazairin telah menciptakan sebuah sistim yang lebih padu dan menyeluruh, yakni melalui pendekatan antropologi yang telah membuka peluang menafsirkan ayat-ayat kewarisan dalam kerangka yang lebih luas.

Ketiga, Umar Syihab, Hukum Kewarisan Islam dan Pelaksanaannya di Wajo, disertasi pada Program Pascasarjana IAIN Sultan Alaudin Makasar 1996. Penelitian ini menggunakan pendekatan teologis, sosiologis dan normatif.Penelitian ini 
menyimpulkan bahwa penerimaan syara' oleh sistim Hukum Adat Bugis Wajo "Pangadereng" telah melahirkan pelaksanaan hukum Kewarisan Islam di Wajo.

Keempat, Neng Djubaedah, Pelaksanaan Hukum Waris Islam di Kabupaten Pandeglang Banten, tesis pada Program Pascasarjana Universitas Indonesia (UI) Tahun 2005. Ia menyimpulkan bahwa pelaksanaan hukum waris Islam dalam masyarakat Pandeglang sangat kental dengan nuansa kekeluargaan dan kekerabatan. Meskipun hukum Islam menjadi hukum yang hidup dan berlaku di masyarakat, namun praktek pembagian harta warisan umumnya banyak diselesaikan melalui musyawarah antara anggota keluarga atau ahli waris.

Kelima, Ahmad, Md Yazid, Amalan Mufakat dan Aplikasi Takharuj dalam Pengagihan Pusaka Menurut Perspektif Undang-undang Pusaka Islam, dalam Jurnal Islamiyyat, Bangi Vol. 39, Iss. 1, (2017): 21-28.ISL. Penelitian ini meneliti tentang amalan mufakat yang diwarisi secara turun temuran pada masyarakat Melayu dalam pmabagian harta warsian dan membandingkannya dengan aplikasi takahruj.

Keenam, Penelitian yang ditulis oleh Surwati pada Program Pascasarjana IAIN Imam Bonjol Padang dalam bentuk Tesis tahun 2005, membahas tentang "Problematika Hukum Kewarisan di Pengadilan Agama Padang". Penelitian ini meneliti beberapa kasus kewarisan yang terjadi di Pengadilan Agama Padang, tentang penetapan hak ahli waris.

Sedangkan dalam penelitian ini difokuskan pada kajian tentang kebijakan hukum pembagian warisan dalam hukum kewarisan Islam, dengan menganalisis takharuj yang berkembang dalam mazhab Hanafi dan ishlah yang terdapat dalam Kompilasi Hukum Islam, sebagai sebuah kebijakan hukum dalam penyelesaian kewarisan.

\section{PEMBAHASAN}

Penyesuaian secara takharuj dapat berlaku dalam tiga bentuk. Bentuk pertama, kesepakatan di antara dua orang ahli waris untuk keluarnya salah seorang di antaranya dari pembagian warisan dengan imbalan tertentu yang diberikan oleh pihak lain dari hartanya sendiri (Ibn Abidin, t.t: 811, Musa, 1960: 375). Dalam bentuk pertama ini berarti bahwa orang yang keluar itu menyerahkan hak warisan yang akan diterimanya kepada salah seorang ahli waris lain. Hak itu oleh yang menerimanya digantinya dengan hartanya sendiri. Pada waktu pembagian warisan, di samping menerima haknya sendiri ia juga menerima hak ahli waris yang keluar. Pada hakikatnya, cara ini adalah jual beli hak warisan karena tidak menyangkut kepentingan dan hak ahli waris yang lain, maka kesepakatan ini cukup berlaku di antara dua pihak saja tanpa melibatkan ahli waris yang lain.

Bentuk kedua, persepakatan seluruh ahli waris atas keluarnya salah seorang dari kelompok waris, dengan imbalan yang dipikul bersama dari harta mereka di luar hak yang akan mereka terima dari harta warisan. Pada hakikatnya bentuk kedua ini sama dengan bentuk pertama yaitu ahli waris yang keluar menjual haknya kepada ahli waris yang lain. Bedanya ialah bahwa yang membeli di sini adalah seluruh ahli waris. Dalam pembagiannya sama dengan yang 
pertama yaitu semua ahli waris ditetapkan haknya sesuai dengan ketentuan yang berlaku. Kemudian hak dari yang keluar diberikan kepada ahli waris yang lain. Tentang cara penentuan bagian ahli waris yang keluar untuk ahi waris yang tinggal, tergantung kepada kesepakatan mereka pada waktu membeli hak ahli waris yang keluar.

Bentuk ketiga ialah kesepakatan semua ahli waris atas keluarnya salah seorang di antaranya dari kelompok penerima warisan dengan imbalan tertentu dari harta peninggalan itu sendiri (Ibn Abidin, t.t: 811). Hal ini berarti salah seorang memilih untuk mengambil bentuk tertentu dari harta warisan sedangkan yang lain diserahkannya untuk ahli waris yang tinggal, untuk selanjutnya pembagian berlaku di antara ahli waris yang tinggal itu.

Bila diperhatikan bentuk ketiga ini terlihat bahwa masalahnya berbeda dengan dua bentuk yang di atas karena pada bentuk ketiga ini menyangkut dengan cara pembagian. Artinya ahli waris menempuh cara pembagian yang menurut lahirnya menyimpang dari cara yang ditentukan oleh hukum faraid. Dengan diberikannya hak pilih kepada ahli waris untuk menentukan bagiannya yang ada kemungkinan lebih kurang dari hak yang semestinya diterimanya, menyalahi prinsip ijbari. Dasar yang dipakai oleh ulama yang membenarkan lembaga takharuj itu ialah kerelaan dan kesepakatan pihak yang berhak menerimanya.Para ahli waris adalah orang yang berhak menerima harta tersebut, hingga dapat pula bertindak atas haknya itu sesuai dengan kemauan dan kerelaannya.
Jika dikaitkan dengan pembagian warisan secara takharuj yang membolehkan ahli waris menerima bagian kurang atau melebihi dari bagian yang seharusnya ia terima, - dalam salah satu bentuk takharuj - tentunya akan bertentangan dengan prinsip ijbari dan ayat yang mengatur pembagian waris. Di samping itu, dalam takharuj sebelum dilaksanakan pembagian harta warisan, ahli waris dapat melakukan kesepakatan dalam bentuk ishlah, dengan adanya kerelaan dari ahli waris yang lain. Ishlah yang dimaksud dengan memberikan imbalan sebagai ganti terhadap bagian ahli waris yang mengundurkan diri.

Prinsip ishlah, sesuai dengan isi pasal 183 Kompilasi Hukum Islam menyatakan bahwa "Para ahli waris dapat bersepakat melakukan perdamaian dalam pembagian harta warisan setelah masing-masing ahli waris menyadari bagiannya.( Tim Redaksi Citra Umbara, 2012: 379). Hal ini berarti bahwa dalam pembagian warisan dapat saja dilakukan perdamaian atau kesepakatan di antara ahli waris dengan memberikan bagian waris sesuai dengan kedudukan dan kebutuhan, meskipun ukurannya beda dengan haknya. (Ali, 2015: 313).

Setelah menguraikan kebijakan hukum dalam pembagian warisan baik secara takhäruj yang dikembangkan oleh fikih Hanafiyah dan ishlāh (perdamaian) dalam Kompilasi Hukum Islam, selanjutnya akan dilihat titik perbandingan antara dua kebijakan hukum tersebut untuk melihat mana cara yang paling baik dan tepat ditempuh dalam menyelesaikan pembagian warisan. Patokan yang dijadikan sebagai tolok ukur dalam menentukan mana yang 
paling baik dan tepat itu adalah berdasarkan mana yang paling menguntungkan (banyak manfaatnya) dan sedikit mudharat yang ditimbulkan antara takhāruj yang terkesan rumit dengan ishlāh yang bersifat sederhana. Di samping itu juga dapat dilihat mana yang sedikit benturannya dengan dalil-dalil syara' yang ada.

Ulama Hanafiyah dengan cermat menempatkan takhāruj sebagai salah satu bentuk jual beli harta warisan sehingga membuatnya tidak bertentangan dengan prinsip kewarisan Islam. Pada dasarnya kebijakan hukum dalam pembagian warisan secara takhāruj adalah salah satu cara pembagian harta warisan dengan menggunakan prinsip-prinsip musyawarah. Para ahli waris mempunyai peranan dan pengaruh dalam menentukan cara pembagian dan besarnya bagian dari hak yang akan diterima masing-masing ahli waris (Md. Yazid: 2017, 21-28). Namun pembagian tersebut membuat beberapa prinsip dalam hukum kewarisan Islam diabaikan. Di antara prinsip dalam hukum kewarisan Islam yang diabaikan itu adalah:

1. Menyalahi Prinsip Ijbāri Dalam Hukum Kewarisan Islam.

Kata ijbari secara leksikal mengandung arti paksaan (compulsory), yaitu melakukan sesuatu di luar kehendak sendiri. Begitu pula kata ijbari dalam terminologi Ilmu Kalam mengandung arti paksaan, dengan arti semua perbuatan yang dilakukan oleh seseorang hamba, bukanlah atas kehendak dari hamba tersebut tetapi adalah sebab kehendak dan kekuasan Allah, sebagaimana yang berlaku menurut aliran kalam Jabariyah.
Asas ijbāri mempunyai kedudukan yang sentral dalam timbulnya perbedaan ulama tentang kedudukan hukum pembagian warisan secara takhāruj (Syarifuddin, 2004: 3). Dijalankannya asas ijbāri dalam Hukum Kewarisan Islam mengandung arti bahwa peralihan harta dari seseorang yang telah meninggal kepada ahli warisnya berlaku dengan sendirinya menurut kehendak Allah tanpa tergantung kepada kehendak dari pewaris atau permintaan dari ahli warisnya. Unsur paksaan sesuai dengan arti terminologis tersebut terlihat dari segi bahwa ahli waris terpaksa menerima kenyataan perpindahan harta kepada dirinya sesuai dengan yang telah ditentukan. Prinsip ijbāri bukan hanya dari segi peralihan harta saja, namun juga meliputi bagian yang mesti diterima dan siapa saja yang berhak menerima harta warisan. Apabila dilihat cara pembagian secara takhāruj, peralihan harta itu berlaku atas kehendak dari ahli waris yang dilakukan melalui kesepakatan bersama atau musyawarah, bukan beralih dengan sendirinya. Selain itu, dalam salah satu bentuk pembagian warisan secara takhāruj, bagian warisan yang diterima oleh masingmsiang ahli warispun tidak sesuai dengan ketentuan yang ada dalam nash, bisa saja lebih dari bagian yang seharusnya diterima ahli waris atau kurang yang hanya didasarkan kepada kerelaan ahli waris semata. Hal ini menyalahi prinsip ijbāri dari segi peralihan harta dan bagian yang mesti diterima ahli waris. 
Dalam takhāruj, lebih banyak diserahkan kepada keinginan masingmasing ahli waris karena takhāruj itu dilakukan sebelum pewaris meninggal, ketika hak waris itu belum jelas. Padahal secara prinsip selama pewaris itu belum meninggal maka hak-hak kewarisan itu belum jelas, mungkin harta itu berkurang dan mungkin juga bertambah. Dari segi ini, takhäruj juga berbenturan dengan prinsip ijbāri sebagai salah satu asas dalam hukum kewarisan Islam.

Sementara dalam ishlāh, berdasarkan pasal $183 \mathrm{KHI}$, dinyatakan secara jelas bahwa pembagian itu dilakukan setelah pewaris meninggal. Hak-hak itu telah jelas dan masing-masing ahli waris telah mengetahui bagiannya sekalipun harta itu belum sampai secara langsung ke tangannya. Dari segi ini benturannya dengan dalil-dalil lain tidak terdapat di dalam ishlāh.

2. Cara dan Waktu Peralihan Hak Kewarisan

Salah satu prinsip dalam hukum kewarisan Islam adalah semata akibat kematian. Terjadinya peralihan harta dalam kewarisan dengan adanya peristiwa kematian dari seseorang yang memiliki harta. Demikian juga sebaliknya, bahwa harta warisan ini dapat dikatakan dimiliki dalam arti yang sebenarnya setelah terjadinya pembagian harta warisan itu. Tidak dinamakan warisan bila dilakukan peralihan hak itu sebelum kematian atau sesudah kematian sebelum pembagian harta dengan didahului keinginan dari yang memiliki harta. Kalau yang menjadi sebab adanya kewarisan itu adalah kematian, maka tidak dapat dibantah bahwa peralihan hak secara syara' berlaku saat setelah berlangsungnya kematian, meskipun peralihan hak secara praktis baru dilakukan setelah pembagian warisan (Syarifuddin, 1999: 55).

Adapun dalam pembagian warisan secara takhāruj, pembagian harta secara musyawarah (kekeluargaan) warisan dilakukan sebelum adanya kematian dari yang memiliki harta dan sebelum adanya pembagian hak masing-masing ahli waris. Tidak adanya peristiwa kematian dari yang memiliki harta menyebabkan tidak terjadinya peralihan harta dalam kewarisan, sehingga belum bisa dikatakan bahwa harta warisan itu telah menjadi hak milik ahli waris. Hal ini pun berarti ahli waris tidak memiliki hak dan wewenang apapun terhadap harta tersebut, selama yang memiliki harta belum meninggal. Demikian juga halnya, jika penyelesaian secara kekeluargaan dilakukan sebelum pembagian harta warisan di antara ahli waris yang berhak, menyalahi ketentuan hukum keawarisan Islam.

Adapun dalam Kompilasi Hukum Islam, ishlāh (perdamaian) yang dilakukan oleh ahli waris setelah pewaris meninggal dan harta itu telah menjadi hak milik ahli waris. Artinya, peleburan harta dilakukan setelah masing-masing ahli waris menyadari bagiannya yang kemudian diberikan kepada ahli waris lain sesuai dengan kebutuhan dan keinginan ahli waris, bukan lagi atas nama harta warisan sehingga tidak berbenturan dan 
menyalahi prinsip pembagian dalam hukum kewarisan Islam.

3. Menyalahi Prinsip Jual Beli

Dalam transaksi jual beli, di antara syarat-syarat yang terkait dengan barang yang diperjual belikan adalah:

a. Barang itu ada, atau tidak ada di tempat tetapi pihak penjual menyatakan kesanggupannya untuk mengadakan barang itu. Misalnya, di sebuah toko, karena tidak mungkin memajang barang dagangan semuanya, maka sebagiannya diletakkan pedagang di gudang atau masih di pabrik, tetapi secara meyakinkan barang itu bisa dihadirkan sesuai dengan persetujuan pembeli dengan penjual. Barang di gudang dan dalam proses pabrik itu dihukumkan sebagai barang yang ada.

b. Dapat dimanfaatkan dan bermanfaat bagi manusia. Oleh sebab itu, bangkai, khamar dan darah tidak sah menjadi objek jual beli karena dalam pandangan syara' benda-benda seperti ini tidak bermanfaat bagi muslim.

c. Milik seseorang. Barang yang sifatnya belum dimiliki seseorang tidak boleh diperjualbelikan.

d. Dapat diserahkan saat akad berlangsung atau pada waktu yang disepakati bersama ketika transaksi berlangsung (Al-Zuhaily, tt: 356).

Pendapat ulama Hanafiyah dalam Syarah Fath al-Qadir menyebutkan bahwa takhāruj dibolehkan karena ia adalah sebagai bentuk jual beli harta warisan. Dalam prakteknya memang terjadi seperti jual beli, yaitu ahli waris yang keluar menerima imbalan dari ahli waris yang lain sebagai ganti atas warisan yang menjadi haknya. Hal pokok yang mendasari pendapat ulama Hanafiyah bahwa takhäruj merupakan jual beli harta warisan adalah dengan adanya imbalan yang diberikan ahli waris yang keluar meskipun secara langsung akadnya tidak seperti akad jual beli pada umumnya. Pemberian imbalan itulah yang mengisyaratakan telah terjadi transaksi jual beli antara kedua belah pihak. Di satu sisi, ahli waris yang keluar adalah sebagai pihak penjual dan di sisi lain ahli waris yang menerima adalah sebagai pihak yang membeli. Sedangkan yang menjadi objek dalam transaksi jual beli tersebut adalah bagian atau furudh yang ditinggalkan (Ali Ibn Humam, 1970: 405).

Dalam konteks jual beli sacara umum, ada rukun-rukun yang harus dipenuhi agar jual beli tersebut sah menurut syara'. Rukun-rukun tersebut adalah penjual, pembeli, barang yang diperjualbelikan dan ijab kabul. Namun berbeda dengan rukun jual beli versi ulama Hanafiyah. Menurut ulama Hanafiyah yang menjadi rukun dalam jual beli hanyalah kerelaan kedua belah pihak untuk melakukan transaksi jual beli. Akan tetapi, karena unsur kerelaan itu merupakan unsur hati yang sulit untuk diindera sehingga tidak kelihatan, maka diperlukan indikasi yang menunjukkan kerelaan itu dari kedua belah pihak. Indikasi yang menunjukkan kerelaan kedua belah pihak yang melakukan transaksi jual beli itu tergambar dalam ijab dan qabul atau melalui cara saling memberikan barang dan harga barang (ta'athi). (Ibn Abidin, tt: 5) Penulis melihat bahwa ulama Hanafiyah memandang keabsahan jual beli adalah pada substansi 
pelaksanaannya. Adanya keridaan antara penjual dan pembeli sudah mencakup segalanya yang terkandung dalam proses transaksi, sehingga perpindahan kepemilikan yang disertai keridhaan dari masing-masing pihak telah dianggap sebagai jual beli yang sah dan boleh dilakukan.

Dalam proses pembagian secara takhāruj jelas memang tidak terlihat adanya transaksi jual beli seperti jual beli pada umumnya. Tidak ada yang disebut objek yang diperjualbelikan, karena harta itu belum beralih kepada ahli waris disebabkan pemilik harta yang akan mewarisksan itu belum meninggal. Tidak adanya peralihan harta tersebut menyebabkan tidak ada bentuk harta yang dimiliki oleh ahli waris. Jika dikatakan bahwa bagian atau hak waris dari ahli waris itu menjadi objek dalam transaksi jual beli, sementara bagian yang mesti diterima oleh ahli waris belum ditentukan secara pasti berapa jumlahnya. Kejelasan barang yang diperjualbelikan dalam transaksi jual beli menjadi syarat mutlak dalam transaksi. Dalam transaksi jual beli, objek yang diperjualbelikan itu mesti jelas dan dapat diserahkan pada waktu akad. Sekalipun ada pengecualian dalam bentuk $b a^{\prime} i$ al-salam, namun tetap saja benda yang menjadi objek itu telah ditentukan dan dijelaskan sebelumnya baik secara kualitas atau kuantitasnya. Berdasarkan prinsip tersebut, cara pembagian dalam bentuk takhāruj ini membentur fikih karena tidak sesuai dengan prinsip-prisnip yang berlaku dalam jual beli.

Takhāruj hanya diamalkan di kalangan ulama Hanafiyah, dan tidak diamalkan oleh ulama lain karena adanya perbenturan dengan nash. Bentuk ishläh yang dilakukan dalam takhāruj juga berbenturan dengan hadis dan kaidah fikih bahwa "ishlāh yang berlaku di kalangan orang muslim itu bukanlah ishlāh yang mengharamkan sesuatu yang halal dan menghalalkan sesuatu yang haram." Sebagaimana dalam kaidah:

$$
\text { حراما الصلح جائز بين المسلمين الا صلحا حرم حلالا أو أحل }
$$

"Perdamaian di antara kaum muslimin adalah boleh kecuali perdamaian yang mengharamkan yang halal atau menghalalkan yang haram". (Ibn Taimiyah, 2001: 461).

Pembagian secara ishlāh yang terdapat di dalam Kompilasi Hukum Islam, dapat dikatakan tidak berbenturan dengan prinsip-prinsip yang ada dalam hukum kewarisan Islam dan dalil-dalil syara' yang ada. Hal ini dapat dilihat dalam uraian dengan terlebih dahulu mengkaji dan menghubungkannya dengan hukum menggugurkan hak perorangan dalam Islam.

Dalam kajian hukum Islam hak itu terbagi kepada beberapa kategori. Beberapa kategori itu pada dasarnya adalah pecahan dari dua kategori umum yaitu hak Allah atau disebut juga hak umum, dan hak hamba atau hak perorangan. Adanya kategorisasi hak kepada Allah dan hak kepada hamba bukanlah sebuah pemisahan secara tajam, karena pada prinsipnya, dalam keyakinan umat Islam, semua hukum yang diturunkan Allah itu adalah hak Allah dalam arti wajib ditaati. Kategorisasi tersebut antara lain dalam rangka 
membedakan mana hukum yang dalam penyelesaiannya terdapat jalan penyelesaian alternatif selain hukum yang jelas tertulis, misalnya dengan penyelesaian damai atau secara kekeluargaan dan mana yang tidak punya alternatif sehingga tidak bisa diselesaikan kecuali seperti ketentuan yang tertulis (Efendi, 2004: 340-345).

\section{Hak Allah}

Hak Allah maksudnya adalah hakhak yang merupakan hak Allah dan hak umum yang jika dilanggar akan merusak hubungan antara seseorang dengan Allah, atau hubungannya dengan orang lain, dan bisa mengguncang stabilitas ketenteraman orang banyak. Agar hak-hak Allah ini terpelihara, dalam hukum Islam dibuat aturan-aturan yang berhubungan dengan hak Allah atau hak masyarakat umum. Hak yang termasuk kategori ini antara lain, menjaga kehormatan dan keturunan sehingga dilarang berzina, menjaga harta sehingga dilarang mencuri, merampok dan menipu, untuk menjaga kehormatan agama dilarang riddah, dan untuk menjaga akal pikiran dilarang mengkonsumsi benda yang merusak akal. Pelanggaran terhadap ketentuan-ketentuan tersebut dikenakan sanksi hukum yang disebut sanksi hukum hudud.

\section{Hak Hamba atau Hak Perorangan}

Hak perorangan maksudnya adalah hak-hak yang jika dilanggar, akan merugikan diri perorangan yang bersangkutan, tidak merugikan orang lain. Misalnya, hak yang berhubungan dengan harta benda perorangan. Untuk memelihara hak-hak seperti ini, dalam hukum Islam dirumuskan aturan-aturan hukum dalam bidang muamalat.
Umpamanya, kewajiban mengganti rugi atas diri seseorang yang telah merusak harta benda orang lain, masalah utang piutang, hak seorang pemegang gadai untuk menahan harta gadai dalam kekuasaan dan pemeliharaannya, dan berbagai hak yang berhubungan dengan perikatan seperti dalam jual beli dan sewa menyewa.

Para ahli Ushul Fiqh antara lain Ali Hasaballah (Hasaballah, 1976: 329-333), ahli hukum Islam berkebangsaan Mesir, menjelaskan bahwa hak-hak Allah atau hak umum, sepenuhnya terletak di tangan penguasa untuk melaksanakan hukuman duniawi terhadaap pelanggarnya. Tidak seorang pun, meskipun penguasa itu sendiri, yang bisa menggugurkan atau memaafkan orang yang melanggarnya. Orang yang melakukan zina atau pencurian, bila telah terbukti dan mencukupi syarat-syaratnya, harus dituntut dan dikenai sanksi, dan tidak seorang pun yang bisa memaafkannya. Alasannya, bahwa seorang mukallaf hanya punya hak untuk memaafkan suatu pelanggaran atau menggugurkannya jika berkaitan dengan hak pribadinya. Oleh sebab itu, seseorang tidak berhak memaafkan seseorang yang tidak shalat, puasa, haji, zakat, dan tidak pula menggugurkan sanksi-sanksi hukum atas kejahatan zina dan mencuri, disebabkan semuanya itu bukan merupakan pelanggaran hak perorangan. Dengan demikian, seseorang yang berzina dengan isteri tetangganya, tidak bisa diselesaikan secara kekeluargaan atau damai. Begitu pula tidak ada perdamaian dalam masalah pencurian. Pelakunya harus dikenakan hukuman yang sudah ditentukan. 
Adapun taklif yang berkaitan dengan hak hamba (hak perorangan) dalam fiqh Islam merupakan ketentuan-ketentuan hukum yang berhubungan dengan bidang ini, jika dilanggar maka sepenuhnya diserahkan kepada pemilik hak yang dilanggar, apakah ia akan menuntut atau memaafkannya. Begitu juga tentang penyelesaian hak dalam bentuk ini bisa diselesaikan secara damai atau secara kekeluargaan. Misalnya, seseorang yang memecahkan kaca mobil orang lain, maka diserahkan pada pihak yang punya mobil, apakah ia akan meminta ganti rugi atau merelakannya. Demikian pula seseorang yang berpiutang kepada pihak lain, maka yang berpiutang bebas memilih antara tetap menagih piutangnya atau membebaskannya tanpa perlu membayarnya.

Kembali pada kasus yang dibahas ini, hak seseorang untuk mewarisi dari pewarisnya apakah termasuk kategori hak Allah (hak umum) atau hak hamba (hak perorangan). Jika merujuk kepada pendapat seorang ulama terkemuka berkebangsaan Mesir, Muhammad Abu Zahrah dalam karyanya Usül al-Fiqh yang menegaskan bahwa hak seseorang untuk mewarisi harta peninggalan pewarisnya yang meninggal dunia termasuk ke dalam kategori hak hamba atau hak perorangan (Zahrah, tt: 105). Secara murni ia mensejajarkan hak untuk mewarisi dengan hak untuk menagih atau menerima piutang dan masalah-masalah lain yang berhubungan dengan pemilikan harta. Setelah menegaskan bahwa hak mewarisi adalah hak hamba secara murni, Abu Zahrah menjelaskan lebih lanjut bahwa: "Melanggar hak hamba adalah sebuah kezaliman". Allah tidak menerima tobat seseorang yang memakan hak hamba, kecuali jika yang bersangkutan membayar hak itu kepada pemiliknya atau dimaafkan oleh pemilikya. Hak semacam ini tidak lain adalah untuk memelihara kemaslahatan perorangan. Oleh karena itu, hak seperti ini bisa digugurkan oleh pemilik hak."

Berdasarkan keterangan Abu Zahrah tersebut, dalam pembagian harta warisan, jika setiap pihak ahli waris secara rela membaginya secara kekeluargaan, bisa dibagi secara kekeluargaan atau secara damai sesuai dengan kesepakatan setiap pihak yang terkait. Bahkan berdasarkan hal tersebut, jika ada di antara ahli waris yang merelakan atau menggugurkan haknya dalam pembagian harta warisan itu untuk diserahkan kepada ahli waris yang lain maka itu boleh dilakukan. Harta warisan boleh dibagi secara kekeluargaan inilah yang diakui pasal 183 Kompilasi Hukum Islam.

Dalam literatur-literatur hukum Islam dikemukakan, bahwa peluang untuk memilih apakah akan melaksanakan ketentuan hukum Islam atau memilih berdamai hanya dibolehkan apabila mencukupi dua syarat yaitu pada ketentuan yang mengatur hak-hak hamba, dan atas persetujuan seluruh pihak yang mempunyai hak. Persyaratan terakhir ini diperlukan, agar tidak ada pihak yang merasa dirugikan.

Dengan demikian dapat disimpulkan bahwa jika ahli waris ingin melakukan kesepakatan dalam pembagian harta warisan sesuai dengan kebutuhan mereka masing-masing, dapat dibenarkan sejauh harta itu telah menjadi hak masing-masing ahli waris. Artinya, setelah dilakukan pembagian warisan 
dengan menentukan hak masing-masing ahli waris sesuai dengan furüdh yang mesti diterima, kemudian harta dilebur kembali dan dilakukan kesepakatan dengan membagi harta warisan sesuai dengan kebutuhan masing masing ahli waris. Sebaliknya, jika ahli waris melakukan kesepakatan terhadap sesuatu yang belum tentu dan belum jelas menjadi haknya, hal ini tidak bisa dilakukan karena ahli waris melakukan kesepakatan atau perdamaian terhadap sesuatu yang bukan menjadi hak mereka. Berdasarkan ketentuan inilah dapat dikatakan bahwa dalam pembagian warisan yang dilakukan secara takhāruj, ahli waris belum memiliki harta dalam bentuk warisan karena belum dilakukan pembagian warisan disebabkan pewaris belum meninggal. Selama harta belum dimiliki, ahli waris tidak punya hak sama sekali terhadap harta itu. Berbeda halnya dengan perdamaian (ishläh) yang terdapat dalam KHI. Ishlāh dalam KHI menunjukkan bahwa pembagian warisan yang dilakukan secara ishlāh itu dilakukan setelah masing-masing ahli waris menyadari bagiannya, artinya setelah ada hak mereka terhadap harta tersebut. Sehingga jika mereka ingin menghibahkan, atau memberikan kepada ahli waris lain, atau meleburnya dan memberikan kepada siapapun yang dikehandaki dan membutuhkan, hal ini dibolehkan karena harta itu telah menjadi hak milik ahli waris.

Dilihat dari sisi kemashlahatan, dalam penyelesaian pembagian warisan dalam takhāruj ataupun ishlāh menurut KHI, dapat dilihat dari beberapa segi. Dengan mengkaitankannya dengan perkara yang dibahas ini, hukum faraid adalah termasuk dalam kategori hukum yang mengatur kebutuhan daruriyat, karena jika pembagian harta warisan itu tidak dapat berjalan lancar, bisa mengancam eksistensi hubungan silahturrahmi antara keluarga. Oleh karena demikian penting peranan hukum faraid ini dalam upaya menghindarkan putusnya silahturrahmi maka Al-Qur'an telah secara khusus membicarakan masalah ini secara lebih rinci. Oleh sebab itu terkenal di kalangan ulama, bahwa di antara hukum Islam yang sangat rinci dalam Al-Qur'an adalah hukum faraid. Dalam gambaran Islam, bila hukum faraid itu dijalankan secara jujur dan benar, maka kekhawatiran adanya dampak negatif dari pengaruh harta yang ditinggalkan si mati, bisa dihindarkan atau minimal bisa ditekan ke atas yang lebih ringan. Artinya, dengan terlaksananya hukum faraid, di samping hak warisan dapat dikembalikan secara benar kepada yang punya hak, juga yang sangat mendasar adalah mampu membuat keluarga yang bersangkutan hidup damai seperti semula.

Untuk mencapai tujuan itu tidak bisa mengandalkan keputusan hakim di pengadilan, tetapi berkaitan erat dengan banyak hal. Terutama adanya kesadaran serta kesiapan mental dari pihak-pihak yang bersangkutan untuk menerima segala konsekuensi dari penerapan hukum faraid atau perlu adanya kesiapan para pihak untuk mundur setapak dari sikapnya jika dengan itu bisa dicapai penyelesaian yang tidak berdampak negatif terhadap tali persaudaraan. Tanpa adanya kesiapan mental seperti ini, tujuan hukum faraid untuk memberikan ketenteraman pada masing-masing pihak tidak akan tercapai. Putusnya tali persaudaraan disebabkan sengketa harta 
warisan, adalah refleksi dari sikap yang berlebihan mencintai harta dan mengabaikan hubungan persaudaraan. Padahal dalam ajaran Islam harta bukan untuk membuat orang berjarak dari saudaranya, tetapi justru sebaliknya untuk membina keakraban sesamanya. Tujuan inilah yang hendak diwujudkan oleh hukum faraid.

Jika dihubungkan dengan kajian fikih siyasah di mana objek bahasannya tentang kekuasaan, meliputi hukum tata negara, administrasi negara, hukum internasional dan hukum ekonomi. Apabila dilihat dari sisi hubungan, fikih siyasah berbicara tentang hubungan antara rakyat dan pemimpinnya sebagai penguasa yang kongkrit di dalam ruang lingkup satu negara atau antarnegara atau dalam kebijakan-kebijakan ekonominya baik nasional maupun internasional. Dalam kaidah fikih dinyatakan bahwa:

$$
\text { تصرف الامام على الرعية منوط بالمصلحة }
$$

“Kebijakan seorang pemimpin terhadap rakyatnya bergantung kepada kemashlahatan". (Tajuddin, 1991: 134).

Kaidah ini menegaskan bahwa seorang pemimpin harus berorientasi kepada kemashlahatan rakyat, bukan mengikuti keinginan hawa nafsunya atau keinginan keluarganya atau kelompoknya. Banyak contoh yang berhubungan dengan kaidah tersebut yaitu setiap kebijakan yang mashlahat dan manfaat bagi rakyat maka itulah yang harus direncanakan, dilaksanakan, diorganisasikan dan dinilai atau dievaluasi kemajuannya. Sebaliknya, kebijakan yang mendatangkan mafsadah dan memudaratkan rakyat, itulah yang harus disingkirkan dan dijauhi.
Dasar dalam membuat suatu kebijakan adalah dengan memikirkan kemashlahatan. Mashlahah itu bisa dipilih dengan tidak menyulitkan, lebih menguntungkan.Kebijakan pemerintah terhadap rakyat dasarnya adalah mashlahah. Pemerintah yang dimaksud adalah hakim, dalam bentuk yang sebenarnya adalah umara'.Sekalipun dasar kebijakan itu adalah kemashlahatan namun tidak terlepas dari tuntunan agama secara penuh.

Berdasarkan uraian di atas, dapat disimpulkan bahwa pada prinsipnya dalam takhāruj, ulama Hanafiyah juga berusaha untuk tidak melanggar faraidh, namun karena harta itu belum pasti, hal itu yang menyebabkan sulit untuk mengatakan sebagai transaksi jual beli. Seseorang dapat saja melepaskan haknya apakah dalam bentuk jual beli, hibah, wakaf, dan lainnya jika hak itu telah pasti. Berbeda halnya dengan ishläh dalam KHI, jika ahli waris ingin melepaskan hanya, hak tersebut telah pasti sehingga tidak ada benturannya. Inilah salah satu keistimewaan ishläh dalam KHI. Apabila dikaitkan dengan takhäruj dalam konsep ulama Hanafiyah di atas, secara lughawi, ishläh yang terdapat dalam KHI dapat disebut juga sebagai takhāruj dalam arti keluar dari hak. Akan tetapi, bukan dalam pengertian takhāruj yang dibuat oleh ulama Hanafiyah karena takhāruj itu melepaskan hak dan menerima imbalan atas hak yang dilepaskan.

Penelitian ini secara teoritis memang mengkaji persoalan klasik yaitu satu bentuk kebijakan hukum sacara takhāruj yang kemudian dibandingkan dengan ishläh dalam KHI. Namun hasil dari penelitian ini dapat menjawab persoalan 
penyelesaian pembagian harta warisan banyak yang muncul di zaman kekinian. Dalam penyelesaian pembagian harta warisan di zaman sekarang tidak dapat dihindarkan banyak pihak yang memiliki keinginan untuk menyelesaikannya secara kekeluargaan atau musyawarah di kalangan ahli waris supaya harta tersebut dapat diberikan dan dimanfaatkan oleh ahli waris yang lebih membutuhkan.

Bahkan mungkin adanya keinginan ahli waris untuk tidak membagi harta warisan. Agar cara yang dilakukan itu tidak menyimpang dari ketentuan umum yang berlaku dan ahli waris menerima hak dalam keadaan merasa puas sehingga dapat dinyatakan apa yang dipraktekkan tidak salah atau melanggar hukum maka penyelesaian secara ishlāh dalam KHI ini merupakan solusi paling tepat untuk dilakukan karena mudah dilakukan dan rasional.

Apabila dalam penyelesaian secara kekeluargaan di atas, terdapat perbedaan di antara ahli waris sehingga tidak merasa senang dengan hak yang diterima maka dalam kondisi seperti ini hakim yang berwenang memutuskan perkara pembagian harta warisan sesuai dengan apa yang ditentukan oleh nash. Keputusan hakim ini mesti dipatuhi oleh para pihak karena keputusan hakim tersebut mengikat terhadap setiap ahli waris.

\section{PENUTUP}

\section{Kesimpulan}

Dalam menyelesaian pembagian warisan dalam Islam dapat ditempuh kebijakan hukum selama kemashlahatan menghendakinya dan tidak menyalahi dalil-dalil yang qath'i dalam al-Qur'an dan Hadis. Ulama Hanafiyah menempuh cara takhāruj (keluarnya seorang atau lebih ahli waris dari kelompok ahli waris dengan imbalan yang diberikan oleh ahli waris yang lain baik dengan menggunakan hartanya sendiri atau dari harta warisan). Namun dalam penyelesaian secara takhāruj ini terdapat titik-titik lemah sehingga ulama di luar Hanafiyah tidak mengamalkannya. Titik-titik lemah tersebut berpotensi menyalahi dalil-dalil yang qath'i dan prinsip umum dalam muamalah māliyah. Kompilasi Hukum Islam di Indonesia pasal 183 menetapkan perdamaian (ishlāh) sebagai bentuk kebijakan hukum. Perdamaian (ishlāh) dalam Kompilasi Hukum Islam ini lebih mudah untuk diikuti dan tidak menyalahi dalil-dalil yang qath' $i$ dalam al-Qur'an dan Hadis. Adanya perbandingan kedua kebijakan hukum tersebut di atas, dapat disimpulkan bahwa kebijakan hukum dalam bentuk perdamaian (ishlāh) yang ditetapkan oleh Kompilasi Hukum Islam lebih baik dan tepat untuk diterapkan dalam hukum kewarisan Islam di Indonesia karena tidak berpotensi menyalahi dalil-dalil syara' dan prinsip umum dalam muamalah māliyah. Dengan caraishlāh dalam KHI, dapat menjadi jawaban terhadap penyelesaian kewarisan yang banyak dipraktekkan dalam masyarakat muslim Indonesia, karena mudah dan rasional.

\section{Saran}

1. Disarankan kepada pihak yang menyelesaikan perkara warisan, ketika menemukan kesulitan dalam penyelesaiannya dapat menempuh kebijakan hukum yang secara lahir mungkin dianggap menyalahi 
ketentuan kewarisan, namun tidak menyalahi dalil-dalil yang qath'i dalam al-Qut'an dan Hadis.

2. Disarankan kepada para pihak yang akan menerima harta warisan, agar harta yang diterima tidak bercampur dengan hak orang lain, diupayakan dalam pembagian harta warisan dilakukan tidak melanggar dari ketentuan umum dan prinsip dalam kewarisan.

\section{DAFTAR KEPUSTAKAAN}

Ahmad, Md Yazid, Amalan Mufakat dan Aplikasi Takharuj dalam Pengagihan Pusaka Menurut Perspektif Undangundang Pusaka Islam, dalam Jurnal Islamiyyat;

Bangi Vol. 39, Iss. 1, (2017): 21-28.ISL.

Ali, Mohammad Daud, Hukum Islam, Pengantar Ilmu Hukum dan Tata Hukum di Indonesia, Jakarta: PT Raja Grafindo Persada, 2005, hlm. 313.

Efendi, Satria, 2004, Problematika Hukum Keluarga Islam Kontemporer. Jakarta: Kencana. Cet. ke-1

Hasaballah, Ali. 1976, Ushul al-Tasyri' alIslami, Mesir: Dar al-Ma'arif. 1976. cet. ke-5

Ibn Abidin, tt. Hasyiyah Radd al-Muhtar 'ala ad-Durr al-Mukhtar. Beirut: Dar alKutub al-Ilmiyah. Juz. IV dan VI. Cet.ke-2
Ibnu al-Humam, 1970, Syarh Fath al-Qadir. Mesir: Mustafa al-Babiy al-Halabiy. Juz.8

Ibn Qudamah, 1970, al-Mughniy. Kairo: Maktabah al-Qahiriyah. Juz. VI

Ibn Taimiyah, 2001, al-Qawa'id alNuraniyah al-Fiqhiyah. Riyadh: Maktabah al-Rusyd. Cet. ke-Juz. II

Musa,Yusuf, 1960, at-Tirkah wa al-Mirast fi al-Islam, Kairo: Dar al-Ma'rifah

Al-Subki, Imam Tajuddin 'Abd al-Wahab, 1991, al-Asybah wa al-Nazhair. Beirut: Dar al-Kutub al-Ilmiyah. Cet. ke-1

Syarifuddin, Amir, 2004, Hukum Kewarisan Islam, Jakarta: Prenada Media 1999, Permasalahan Dalam Pelaksanaan Faraid. Padang: IAIN IB Press

2004, Hukum Kewarisan Islam, Jakarta: Kencana, Prenada Media. Ed.1. Cet.ke- 1

Tim Redaksi Citra Umbara, Kompilasi Hukum Islam, Bandung: Citra Umbara, 2012: 379

Zahrah, Muhammad Abu, t.t. Ushul alFigh. Kairo: Dar al-Fikr al-Arabiy

Al-Zuhaily, Wahbah, 1997, al-Figh alIslamiy wa Adillatuhu. Damsyiq: Dar al-Fikr. Juz. 8 dan 10. 